\title{
DUKUNGAN SOSIAL MENINGKATKAN KUALITAS HIDUP LANSIA : REVIEW ARTICLE
}

\author{
May Dwi Yuri Santoso \\ RSUD dr. Soehadi Prijonegoro Sragen \\ Email: maydwiyurisantoso@gmail.com
}

\begin{abstract}
Elderly is one of the developmental periods characterized by a decrease in physical, psychological and social functions. This decrease in function can reduce the quality of life of the elderly. To improve the quality of life of the elderly a social support is needed. The social support aims to help the elderly to fulfill their life needs. The purpose of this article review is to review various articles regarding social support for the quality of life of the elderly so that it can be used as information data so that the elderly do not experience problems of lack of attention or affection, feeling lonely, depressed and feeling useless, thus fulfilling their life needs. The method used is a scientific electronic bibliographic database of articles published through Google Scholar as many as 2,680,000 articles and from Google Scholar 6,320 articles, then 10 articles are selected. The results of a review of 10 articles that have been chosen state that social support improves the quality of life for the elderly. Social support is defined as the existence or presence of someone who is trustworthy, understanding, caring and loving, from the closest people such as children, family, and society that are needed by the elderly to live the rest of their lives because it is a support system for the elderly to be active amid the limitations experienced.
\end{abstract}

Key words: Social Support, Quality of Life, Elderly

Abstrak : Lansia merupakan salah satu masa perkembangan yang ditandai dengan menurunnya fungsi fisik, psikologis dan sosial. Penurunan fungsi tersebut dapat menurunkan kualitas hidup lansia. Untuk meningkatkan kualitas hidup lansia diperlukan sebuah dukungan sosial. Dukungan sosial tersebut bertujuan untuk membantu lansia dalam memenuhi kebutuhan hidupnya. Tujuan review article ini adalah untuk mengulas berbagai artikel mengenai dukungan sosial terhadap kualitas hidup lansia sehingga dapat dijadikan sebagai data informasi agar lansia tidak mengalami masalah kurang perhatian atau kasih sayang, merasa kesepian, depresi dan merasa tidak berguna, sehingga terpetuhinya kebutuhan-kebutuhan hidupnya. Metode yang digunakan adalah database bibliografi elektronik ilmiah dari artikel yang telah dipublikasikan melalui Google Scholar sebanyak 2.680.000 artikel dan dari Google Cendekia sebanyak 6.320 artikel, kemudian dipilih 10 artikel. Hasil review dari 10 artikel yang telah dipilih menyatakan dukungan sosial meningkatkan kualitas hidup lansia. Dukungan sosial didefinisikan sebagai keberadaan atau adanya seseorang yang dapat dipercaya, memahami, memperhatikan dan mencintai, dari orang-orang terdekat seperti anak, keluarga, maupun masyarakat sangat diperlukan lansia dalam menjalani sisa hidupnya karena merupakan sistem pendukung bagi lansia untuk dapat terus aktif ditengah keterbatasan yang dialaminya.

Kata kunci: Dukungan Sosial, Kualitas Hidup, Lansia

\section{PENDAHULUAN}

Menua atau menjadi tua adalah suatu proses menghilangnya secara perlahan-lahan kemampuan jaringan untuk memperbaiki diri atau mengganti dan mempertahanakan fungsi normalnya sehingga tidak dapat bertahan terhadap infeksi dan memperbaiki kerusakan yang diderita (Nugroho, 2011).

Menua adalah suatu keadaan yang akan terjadi didalam kehidupan manusia. Proses menua pada lansia mempengaruhi berbagai aspek kehidupan yaitu sosial, ekonomi dan terutama kesehatan karena semakin bertambahnya usia seseorang maka fungsi organ tubuh juga akan semakin menurun. Menurut UU No. 13/Tahun 1998 tentang Kesejahteraan Lansia disebutkan bahwa lansia adalah seseorang yang berusia lebih dari 60 tahun (Dewi. S.R, 2014).

Lansia adalah tahap akhir dalam proses kehidupan yang akan terjadi banyak penurunan dan perubahan fisik, psikologi, sosial yang saling berhubungan satu sama lain, sehingga berpotensi menimbulkan masalah kesehatan fisik maupun jiwa pada lansia (Cabrera. A.J, 2015).

Pada masa lansia seseorang mengalami kemunduran fisik, mental, dan sosial sedikit demi sedikit sampai tidak dapat melakukan tugasnya sehari-hari lagi sehingga bagi kebanyakan orang, masa tua merupakan masa yang kurang menyenangkan (Nugroho, 2011). 
Lansia menginginkan kehidupan yang sejahtera dimana terpenuhinya kebutuhankebutuhan hidupnya. Kesejahteraan sama dengan peningkatan kualitas hidup, yang mana kualitas hidup memiliki arti kepuasan hidup atau terpenuhinya kebutuhan hidup berdasarkan kondisi fisik, psikologis dan kondisi sosial yang dirasakan seseorang (Pratiwi. Y, 2018).

Kualitas hidup sebagai persepsi individu terhadap kehidupannya di masyarakat dalam konteks budaya dan sistem nilai yang ada, terkait dengan tujuan, harapan, standar dan perhatian. Kualitas hidup merupakan suatu konsep yang sangat luas yang dipengarui kondisi fisik individu, psikologis, tingkat kemandirian, serta hubungan individu dengan lingkungan (Yuliati. A, 2014).

Kualitas hidup lansia dapat ditentukan oleh berbagai faktor karena konsepnya yang multidimensi. Kualitas hidup merupakan "...persepsi individu terhadap posisinya dalam kehidupan baik secara konteks budaya dan sistem nilai dimana mereka tinggal dan berkaitan dengan tujuan, harapan, standar, dan perhatian" (WHOQOL, 1997).

Salah satu faktor yang mempengaruhi kualitas hidup lansia adalah dukungan sosial

\section{METODE}

Metode yang digunakan dalam review article dengan menggunakan metode sistematik berdasarkan Preferred Reporting Items for Systematic reviews and Meta-Analyses (PRISMA) (Moher. D., Liberati. A, Tetzlaff. J.,
(Wedgeworth. M., LaRocca. M.A., Chaplin. W.F., Scogin. F, 2017). Dukungan sosial merupakan suatu proses hubungan yang terbentuk dari individu dengan persepsi bahhwa seseorang dicintai dan dihargai, disayangi untuk memberikan bantuan kepada individu yang mengalami tekanan-tekanan dalam kehidupan (Raafiah.D, 2012).

Dukungan sosial serta kepedulian pada lansia diperoleh dari keluarga, kerabat dan masyarakat sangat diperlukan dan berguna bagi lansia sehingga dapat mempertahankan kemandirian dan seminimal mungkin memiliki ketergantungan pada orang lain, dengan memberikan dukungan dan merubah perilaku ketergantungan lansia (Arini. D., Hamiyati., Tarma, 2016).

Hasil beberapa penelitian menunjukkan dukungan sosial dapat meningkatkan kualitas hidup lansia. Tujuan review article ini adalah untuk mengulas berbagai artikel mengenai dukungan sosial terhadap kualitas hidup lansia sehingga dapat dijadikan sebagai data informasi agar lansia tidak mengalami masalah kurang perhatian atau kasih sayang, merasa kesepian, depresi dan merasa tidak berguna, sehingga terpetuhinya kebutuhan-kebutuhan hidupnya.

Altman. D.G, 2009). Penulis mencari artikel yang telah dipublikasikan di dalam database bibliografi elektronik ilmiah dalam bahasa inggris dari Google Scholar dan dalam bahasa Indonesia dari Google Cendekia.

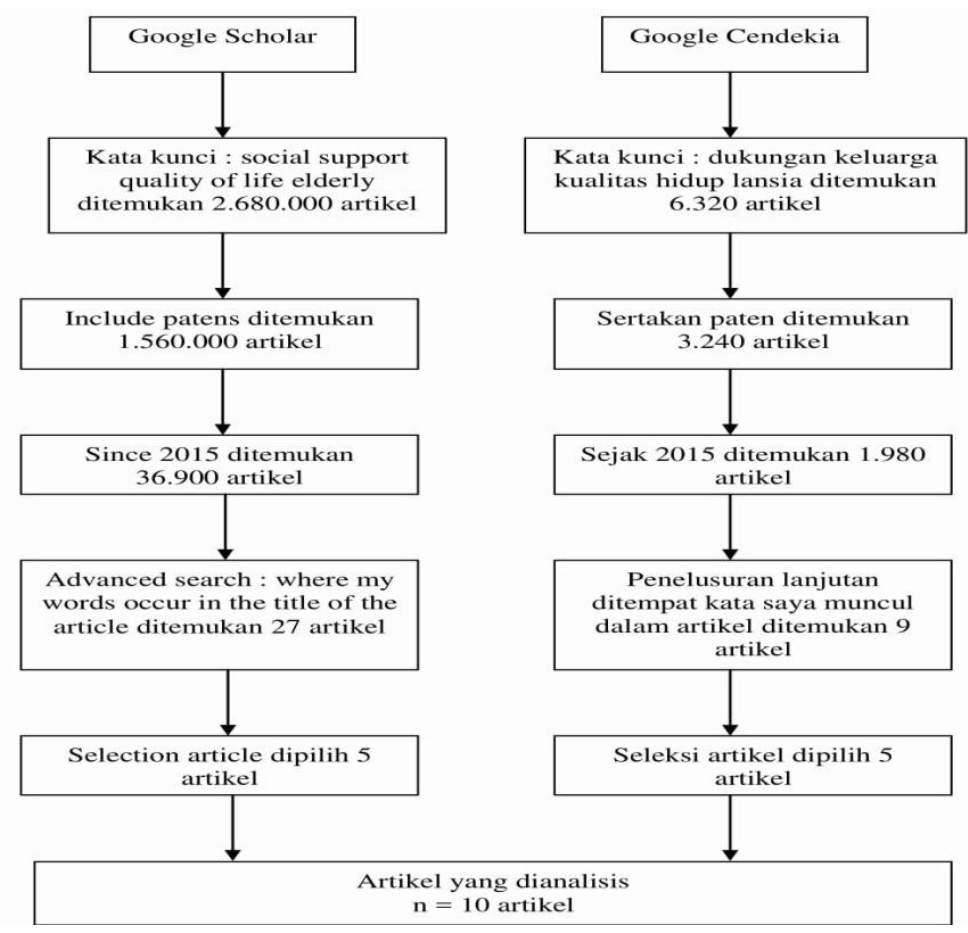

Gambar 1. Flowchart Proses 
Kata kunci (keyword) yang digunakan adalah untuk artikel dalam bahasa Inggris yaitu "Social Support-Quality Of Life-Elderly" dalam bahasa Indonesia "Dukungan SosialKualitas Hidup-Lansia" Hasil pencarian ditemukan pada Google Scholar sebanyak 2.680.000 artikel dan dari Google Cendekia sebanyak 6.320 artikel.

Artikel yang ditemukan dispesifikkan berdasarkan kriteria inklusi yaitu artikel dipublikasikan dalam rentang waktu 20152019 ditemukan pada Google Scholar sebanyak 36.900 artikel dan dari Google Cendekia sebanyak 1.980 artikel.

Dilanjutkan menyeleksi artikel sama (duplicate article) yang diterbitkan pada Google Scholar dan Google Cendekia, berdasarkan kesesuain judul artikel dengan

\section{HASIL}

Dari 10 artikel diperoleh 4 metode kuantitatif dengan desain cross sectional study, 2 metode survei dengan pendekatan korelasi, 1 metode kohort longitudinal study, 1 metode korelational uidengan pendekatan cross sectional, 2 metode mix method : 1 deskriptif analitik dengan pendekatan cross sectional dan 1 deskriptif kuantitatif dengan tujuan review article, Kriteria Inklusi: a) Artikel menggunakan rancangan kuantitatif, kualitatif maupun mix method, b) Fulltext artikel dapat diakses, c) Artikel diterbitkan dari tahun 20152019. Kriteria Eksklusi: a) Metode tidak jelas, b) Artikel merupakan sistematic review, c) Editorial tidak jelas, d) Tidak terlihat korelasi dalam hasil.

Cara penelusuran artikel dapat dilihat dari gambar 1. Selanjutnya melakukan screening berdasarkan seleksi judul, abstrak dan fulltext. Pada tahap akhir seleksi ditemukan 10 artikel menggunakan teknik snow balling sesuai kriteria inklusi dan eksklusi, maka dipilihlan 5 artikel bahasa Inggris dan 5 artikel bahasa Indonesia sehingga ada 10 artikel yang akan dianalisis.

Tabel 1. Hasil Analisis Review Article

\begin{tabular}{|c|c|c|c|c|c|}
\hline No & $\begin{array}{c}\text { Nama peneliti } \\
\text { dan tahun } \\
\text { publikasi }\end{array}$ & $\begin{array}{l}\text { Rancangan } \\
\text { penelitian }\end{array}$ & $\begin{array}{c}\text { Sumber data } \\
\text { dan metode } \\
\text { pengumpulan } \\
\text { data }\end{array}$ & $\begin{array}{c}\text { Jumlah } \\
\text { sampel atau } \\
\text { informan }\end{array}$ & Hasil temuan kunci \\
\hline 1 & $\begin{array}{l}\text { Beatrix. Y., } \\
\text { Kodoatie., } \\
\text { Sekplin. A.S., } \\
\text { Sekeon., } \\
\text { Chreisye. } \\
\text { K.F., } \\
\text { Mandagi, } \\
\text { tahun } 2018\end{array}$ & $\begin{array}{l}\text { Kuantitat } \\
\text { if cross } \\
\text { sectional } \\
\text { study }\end{array}$ & $\begin{array}{l}\text { Kuesioner EQ- } \\
5 \mathrm{D}-5 \mathrm{~L} \text { untuk } \\
\text { mengukur } \\
\text { kualitas hidup } \\
\text { lansia, } \\
\text { kuesioner } \\
\text { dukungan } \\
\text { sosial, dan } \\
\text { kuesioner } \\
\text { kohesi sosial. }\end{array}$ & $\begin{array}{l}72 \text { lansia di } \\
\text { Desa } \\
\text { Tambun } \\
\text { Kecamatan } \\
\text { Likupang } \\
\text { Barat } \\
\text { Kabupaten } \\
\text { Minahasa } \\
\text { Utara }\end{array}$ & 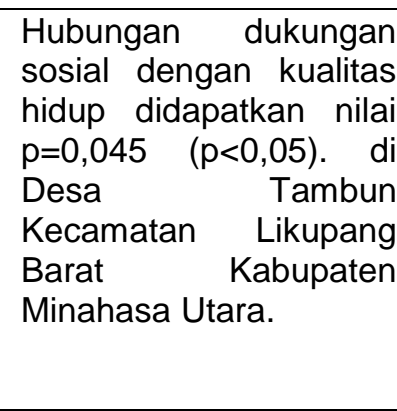 \\
\hline 2 & $\begin{array}{l}\text { Arini. D., } \\
\text { Hamiyati., } \\
\text { Tarma } \\
\text { tahun } 2016\end{array}$ & $\begin{array}{l}\text { Metode } \\
\text { survei } \\
\text { dengan } \\
\text { pendekat } \\
\text { an } \\
\text { korelasi }\end{array}$ & $\begin{array}{l}\text { Kuesioner } \\
\text { dukungan } \\
\text { sosial keluarga } \\
\text { dari } \\
\text { penelitian } \\
\text { terkait dan } \\
\text { kuesioner } \\
\text { kualitas hidup } \\
\text { (WHOQOL- } \\
\text { BREF) yang } \\
\text { dibuat oleh } \\
\text { World Health } \\
\text { Organization } \\
\text { (WHO) }\end{array}$ & $\begin{array}{l}44 \text { orang } \\
\text { lansia di } \\
\text { Panti } \\
\text { Werdha Ria } \\
\text { Pembangun } \\
\text { an Jakarta } \\
\text { Timur }\end{array}$ & 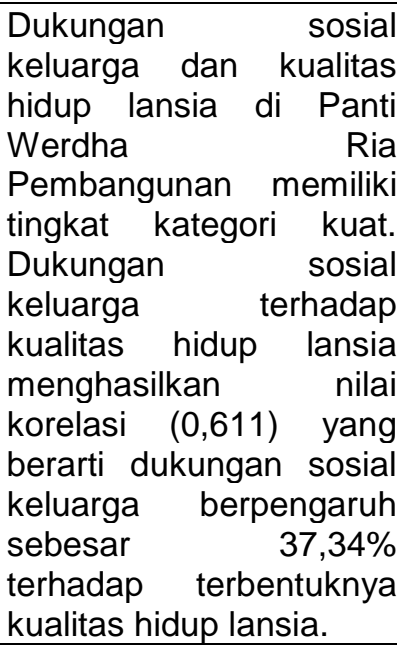 \\
\hline
\end{tabular}




\begin{tabular}{|c|c|c|c|c|c|}
\hline No & $\begin{array}{l}\text { Nama peneliti } \\
\text { dan tahun } \\
\text { publikasi }\end{array}$ & $\begin{array}{l}\text { Rancangan } \\
\text { penelitian }\end{array}$ & $\begin{array}{c}\text { Sumber data } \\
\text { dan metode } \\
\text { pengumpulan } \\
\text { data }\end{array}$ & $\begin{array}{l}\text { Jumlah } \\
\text { sampel atau } \\
\text { informan }\end{array}$ & Hasil temuan kunci \\
\hline 3 & $\begin{array}{l}\text { Winahyu. } \\
\text { K.M., } \\
\text { Winahyu., } \\
\text { Wahyuniati } \\
\text {. S., } \\
\text { Sekarsari. } \\
\text { R, tahun } \\
2017\end{array}$ & $\begin{array}{l}\text { Deskripti } \\
f \text { analitik } \\
\text { dengan } \\
\text { pendekat } \\
\text { an cross } \\
\text { sectional }\end{array}$ & $\begin{array}{l}\text { Kuesioner } \\
\text { baku } \\
\text { Multidimension } \\
\text { al Scale of } \\
\text { Perceived } \\
\text { Social Support } \\
\text { (MSPSS) dan } \\
\text { World Health } \\
\text { Organization } \\
\text { Quality of Life } \\
\text { (WHOQOL)- } \\
\text { BREF yang } \\
\text { telah diuji } \\
\text { validitas dan } \\
\text { reliabilitas. }\end{array}$ & $\begin{array}{l}\text { Sebanyak } \\
71 \quad \text { lansia } \\
\text { dengan } \\
\text { hipertensi di } \\
\text { Kota } \\
\text { Tangerang }\end{array}$ & $\begin{array}{l}\text { Hubungan positif yang } \\
\text { signifikan antara } \\
\text { persepsi dukungan } \\
\text { sosial dengan kualitas } \\
\text { hidup lansia dengan } \\
\text { hipertensi di Kota } \\
\text { Tangerang. }\end{array}$ \\
\hline 4 & $\begin{array}{l}\text { Antari. } \\
\text { R.A., } \\
\text { Saktika. T., } \\
\text { Ferianto } \\
\text { tahun } 2016\end{array}$ & $\begin{array}{l}\text { Deskriptif } \\
\text { kuantitatif } \\
\text { dengan } \\
\text { pendekat } \\
\text { an cross } \\
\text { sectional }\end{array}$ & $\begin{array}{l}\text { Kuesioner } \\
\text { dukungan } \\
\text { sosial dan } \\
\text { kuesioner } \\
\text { kualitas hidup }\end{array}$ & $\begin{array}{l}198 \text { lansia } \\
\text { yang berada } \\
\text { di Desa } \\
\text { Cebongan } \\
\text { Sleman } \\
\text { Yogyakarta }\end{array}$ & $\begin{array}{l}\text { Ada hubungan antara } \\
\text { dukungan sosial } \\
\text { dengan kualitas hidup } \\
\text { pada lansia di Desa } \\
\text { Cebongan Sleman } \\
\text { dengan keeratan yang } \\
\text { kuat. }\end{array}$ \\
\hline 5 & $\begin{array}{l}\text { Ridho, } \\
\text { Syuheri. S } \\
\text { tahun } 2016\end{array}$ & $\begin{array}{l}\text { Korelasional } \\
\text { dengan } \\
\text { pendekatan } \\
\text { cross } \\
\text { sectional } \\
\text { study }\end{array}$ & $\begin{array}{l}\text { kuesioner } \\
\text { ISEL dan } \\
\text { WHOQOL- } \\
\text { BREF }\end{array}$ & $\begin{array}{l}80 \text { responden } \\
\text { lansia di } \\
\text { Puskesmas } \\
\text { Nanggalo } \\
\text { Padang }\end{array}$ & $\begin{array}{lr}\text { Hubungan positif yang } \\
\text { signifikan antara } \\
\text { dukungan sosial } \\
\text { keluarga dengan } \\
\text { kualitas hidup lansia } \\
\text { dengan hipertensi } \\
\text { dengan nilai korelasi } \\
\text { sangat kuat dimana } \\
\text { nilai p value }=0,00 \\
\text { dan nilai korelasi } \mathrm{r}= \\
0,844 \text {. Lansia dengan } \\
\text { hipertensi yang } \\
\text { memiliki dukungan } \\
\text { sosial keluarga yang } \\
\text { tinggi memiliki kualitas } \\
\text { hidup yang tinggi. } \\
\end{array}$ \\
\hline 6 & $\begin{array}{l}\text { Unsar. S., } \\
\text { Dindar. I, } \\
\text { Kurt. S, } \\
2015 \\
\text { tahun } 2015\end{array}$ & $\begin{array}{l}\text { Kuantitatif } \\
\text { cross } \\
\text { sectional } \\
\text { study }\end{array}$ & $\begin{array}{l}\text { Kuesioner the } \\
\text { Katz Activities } \\
\text { of Daily Living } \\
\text { Scale, the } \\
\text { Multidimensio } \\
\text { nal Scale of } \\
\text { Perceived } \\
\text { Social } \\
\text { Support, the } \\
\text { European } \\
\text { Quality of } \\
\text { Life-5 } \\
\text { Dimensions } \\
\text { scale and the } \\
\text { Geriatric } \\
\text { Depression } \\
\text { Scale }\end{array}$ & $\begin{array}{lr}912 \text { lansia } \\
\text { di Edirne, } \\
\text { Turki }\end{array}$ & $\begin{array}{l}\text { Lansia dengan tingkat } \\
\text { dukungan sosial dan } \\
\text { aktivitas hidup sehari- } \\
\text { hari yang baik } \\
\text { memiliki kualitas } \\
\text { hidup yang lebih } \\
\text { tinggi dan tingkat } \\
\text { depresi lebih rendah } \\
(p<0,05) \text {. }\end{array}$ \\
\hline
\end{tabular}




\begin{tabular}{|c|c|c|c|c|c|}
\hline No & $\begin{array}{c}\text { Nama peneliti } \\
\text { dan tahun } \\
\text { publikasi }\end{array}$ & $\begin{array}{l}\text { Rancangan } \\
\text { penelitian }\end{array}$ & $\begin{array}{c}\text { Sumber data } \\
\text { dan metode } \\
\text { pengumpulan } \\
\text { data }\end{array}$ & $\begin{array}{c}\text { Jumlah } \\
\text { sampel atau } \\
\text { informan }\end{array}$ & Hasil temuan kunci \\
\hline 7 & $\begin{array}{l}\text { Ma. L., Li. } \\
\text { Y., Wang. } \\
\text { J., Zhu. } \\
\text { H., Yang. } \\
\text { W., Cao. } \\
\text { R., Qian. } \\
\text { Y., Feng. } \\
\text { M, } 2015 \\
\text { tahun } 2015\end{array}$ & $\begin{array}{l}\text { Metode } \\
\text { survei } \\
\text { dengan } \\
\text { pendekatan } \\
\text { korelasi }\end{array}$ & $\begin{array}{l}\text { Kuesioner } \\
\text { Short Form- } \\
36 \quad \text { (SF-36) } \\
\text { questionnaire } \\
\text {, completion } \\
\text { of the Social } \\
\text { Support } \\
\text { Rating Scale } \\
\text { (SSRS), and } \\
\text { BMD } \\
\text { measurement }\end{array}$ & $\begin{array}{l}214 \text { orang } \\
\text { lansia terdiri } \\
\text { kelompok } \\
\text { perlakuan } \\
102 \text { pasien } \\
\text { dengan } \\
\text { osteoporosi } \\
\text { s dan } 102 \\
\text { tanpa } \\
\text { osteoporosi } \\
\text { s di Cina }\end{array}$ & $\begin{array}{l}\text { Kualitas hidup pasien } \\
\text { lansia dengan } \\
\text { osteoporosis } \\
\text { berhubungan dengan } \\
\text { dukungan sosial }\end{array}$ \\
\hline 8 & $\begin{array}{l}\text { Moser. } \\
\text { S., Luxenb } \\
\text { erger. } \\
\text { W., Freidl. } \\
\text { W, } 2017 \\
\text { tahun } 2017\end{array}$ & $\begin{array}{l}\text { Kuantitatif } \\
\text { cross } \\
\text { sectional } \\
\text { study }\end{array}$ & $\begin{array}{l}\text { Kuesioner } \\
\text { Hearing } \\
\text { Handicap } \\
\text { Inventory for } \\
\text { the Elderly } \\
\text { (Ventry and } \\
\text { Weinstein), } \\
\text { Assessment } \\
\text { for Coping } \\
\text { and Stress } \\
\text { (Laireiter), } \\
\text { short form of } \\
\text { the Social } \\
\text { Support } \\
\text { Questionnair } \\
\text { e (Fydrich, } \\
\text { Sommer, } \\
\text { Tydecks, \& } \\
\text { Brähler), and } \\
\text { World Health } \\
\text { Organization } \\
\text { Quality of Life } \\
\text { Scale-Brief } \\
\text { Version } \\
\text { (World Health } \\
\text { Organization) }\end{array}$ & $\begin{array}{l}65 \text { lansia } \\
\text { berumur } \\
\geq 55 \text { tahun di } \\
\text { Austria }\end{array}$ & $\begin{array}{l}\text { Kualitas hidup lansia } \\
\text { (kualitas hidup fisik, } \\
\text { psikologis, lingkungan } \\
\text { dan sosial) } \\
\text { memerlukan } \\
\text { dukungan sosial. }\end{array}$ \\
\hline 9 & $\begin{array}{l}\text { Unalan. } \\
\text { D., Gocer. } \\
\text { S., } \\
\text { Basturk. } \\
\text { M., } \\
\text { Baydur. } \\
\text { H., Ozturk. } \\
\text { A, } 2015 \\
\text { tahun } 2015\end{array}$ & $\begin{array}{l}\text { Kuantitatif } \\
\text { dengan } \\
\text { pendekatan } \\
\text { cross } \\
\text { sectional } \\
\text { study }\end{array}$ & $\begin{array}{l}\text { Kuesioner } \\
\text { Geriatric } \\
\text { Depression } \\
\text { Scale, the } \\
\text { Multidimensio } \\
\text { nal Perceived } \\
\text { Social } \\
\text { Support } \\
\text { Scale, and } \\
\text { the } \\
\text { WHOQOL- } \\
\text { OLD }\end{array}$ & $\begin{array}{l}917 \text { lansia } \\
\text { berusia di } \\
\text { atas } 65 \mathrm{di} \\
\text { Kayseri } \\
\text { Turki }\end{array}$ & $\begin{array}{lr}\text { Dukungan } & \text { sosial } \\
\text { berpengaruh positif } & \text { polit } \\
\text { terhadap } & \text { kualitas } \\
\text { hidup pada lansia, } & \text { sedangkan depresi } \\
\text { berpengaruh secara } & \text { negatif terhadap } \\
\text { kualitas hidup lansia. }\end{array}$ \\
\hline 10 & $\begin{array}{l}\text { Kim. J., } \\
\text { Song. R, } \\
\text { Kim. K.W., } \\
\text { Kim. J.L, } \\
2016 \\
\text { tahun } 2016\end{array}$ & $\begin{array}{l}\text { Kohort } \\
\text { longitudinal } \\
\text { study }\end{array}$ & $\begin{array}{l}\text { Kuesioner } \\
\text { QoL- } \\
\text { Alzheimer's } \\
\text { Disease } \\
\text { (QoL-AD), } \\
\text { Cumulative } \\
\text { Illness Rating } \\
\text { Scale, }\end{array}$ & $\begin{array}{ll}194 & \text { lansia } \\
\text { di } & \text { Korea } \\
\text { Selatan }\end{array}$ & $\begin{array}{lr}\text { Dukungan sosial } \\
\text { berpengaruh } 29,3 \% \\
\text { dari varians dalam } \\
\text { kualitas hidup lansia } \\
\text { yang tinggal di } \\
\text { masyarakat. Di antara } \\
\text { faktor-faktor ini, } \\
\text { prediktor signifikan }\end{array}$ \\
\hline
\end{tabular}




\begin{tabular}{ll}
\hline exercise & kualitas hidup adalah \\
dukungan sosial $(\beta=$ & $0,322, p<0,001)$. \\
Mental State & \\
Examination, & \\
social & \\
activities, The & \\
Medical & \\
Outcomes & \\
Study-Social & \\
Support & \\
Survey & \\
\hline
\end{tabular}

Penelitian yang dilakukan di berbagai Negara menunjukkan dukungan sosial meningkatkan kualitas hidup lansia. Penelitian di Turki terhadap lansia sebanyak 912 diperoleh hasil lansia dengan tingkat dukungan sosial dan aktivitas hidup sehari-hari yang baik memiliki kualitas hidup yang lebih tinggi dan memiliki tingkat depresi lebih rendah (Unsar. S., Dindar. I, Kurt. S, 2015).

Penelitian di Cina terhadap 214 orang lansia terdiri dari kelompok perlakuan 102 pasien dengan osteoporosis dan kelompok kontrol 102 tanpa osteoporosis di Cina diperoleh hasil kualitas hidup pasien lansia dengan osteoporosis berhubungan dengan dukungan sosial (Ma. L., Li. Y., Wang. J., Zhu. H., Yang. W., Cao. R., Qian. Y., Feng. M, 2015).

Penelitian di Austria terhadap 65 lansia berumur $\geq 55$ tahun diperoleh hasil Kualitas hidup lansia (kualitas hidup fisik, psikologis, lingkungan dan sosial) memerlukan dukungan sosial (Moser. S., Luxenberger. W., Freidl. W, 2017).

Penelitian di Kayseri Turki terhadap 917 lansia berusia di atas 65 diperoleh hasil dukungan sosial berpengaruh positif terhadap kualitas hidup pada lansia, sedangkan depresi berpengaruh secara negatif terhadap kualitas hidup lansia (Unalan. D., Gocer. S., Basturk. M., Baydur. H., Ozturk. A, 2015).

Penelitian di Korea Selatan terhadap 194 lansia diperoleh hasil dukungan sosial berpengaruh 29,3\% dari varians dalam kualitas hidup lansia yang tinggal di masyarakat (Kim. J., Song. R, Kim. K.W., Kim. J.L, 2016).

Penelitian di Desa Tambun Kecamatan Likupang Barat Kabupaten Minahasa Utara

\section{PEMBAHASAN}

Lansia dalam konteks eksistensi manusia, yaitu sebagai masa hidup yang memberi mereka kesempatan-kesempatan untuk tumbuh berkembang. Ada juga lanjut usia yang memandang usia tua dengan sikap-sikap yang berkisar antara kepasrahan yang pasif dan pemberontakan, penolakan, dan
Indonesia terhadap 72 lansia diperoleh hasil ada hubungan dukungan sosial dengan kualitas hidup lansia (Beatrix. Y., Kodoatie., Sekplin. A.S., Sekeon., Chreisye. K.F., Mandagi, 2018).

Penelitian di di Panti Werdha Ria Pembangunan Jakarta Timur Indonesai terhadap 44 lansia diperoleh hasil dukungan sosial keluarga dan kualitas hidup lansia di Panti Werdha Ria Pembangunan memiliki tingkat kategori kuat. Dukungan sosial keluarga terhadap kualitas hidup lansia menghasilkan nilai korelasi yang berarti dukungan sosial keluarga berpengaruh sebesar 37,34\% terhadap terbentuknya kualitas hidup lansia (Arini. D., Hamiyati., Tarma, 2016).

Penelitian di di Kota Tangerang Indonesia terhadap 71 lansia dengan hipertensi diperoleh hasil hubungan positif yang signifikan antara persepsi dukungan sosial dengan kualitas hidup lansia (Winahyu. K.M., Wahyuniati. S., Sekarsari. R, 2017).

Penelitian di di Desa Cebongan Sleman Yogyakarta Indonesia terhadap 198 lansia diperoleh hasil ada hubungan antara dukungan sosial dengan kualitas hidup pada lansia di Desa Cebongan Sleman dengan keeratan yang kuat (Antari. R.A., Saktika. T., Ferianto, 2016).

Penelitian di Puskesmas Nanggalo Padang Indonesia terhadap 80 lansia diperoleh hasil hubungan positif yang signifikan antara dukungan sosial keluarga dengan kualitas hidup lansia dengan nilai korelasi sangat kuat yang memiliki dukungan sosial keluarga yang tinggi memiliki kualitas hidup yang tinggi (Ridho.,Syuheri.S,2016).

keputusasaan. Lansia terkunci dalam diri mereka sendiri dan semakin cepat proses kemerosotan jasmani dan mental.Diharapkan lanjut usia dapat melakukan penyesuaian dengan perubahan fisik dan kesehatan yang semakin menurun (Rohmah. A.I.N., Purwaningsih., Bariyah. K, 2012). 
Lansia merupakan salah satu masa perkembangan yang ditandai dengan menurunnya fungsi fisik, psikologis, dan sosial. Penurunan fungsi tersebut dapat menurunkan kualitas hidup (Sari. D.M.P., Lestari. C.Y.D., Putra. E.C.,Nashori. F, 2018).

Kualitas hidup adalah konsep multidimensional yang luas dan biasanya mencakup evaluasi subyektif baik aspek positif maupun negatif dari kehidupan (CDC, 2016). Kualitas hidup merupakan konsep yang kompleks, yang terkait dengan kepuasan individu terhadap seluruh aspek hidupnya mulai dari fisik hingga sosial dan psikologi (Upton. P, 2012).

Kualitas hidup menurut World Health Organozation Quality of Life (WHOQOL) (1997), didefinisikan sebagai persepsi individu mengenai posisi individu hidup dalam konteks budaya dan sistem nilai dimana individu hidup dan hubungannya dengan tujuan, harapan, standar yang ditetapkan dan perhatian seseorang (Nimas., Fitriana. A.T., Ambarani. $\mathrm{K}, 2012$ ).

Lansia banyak mengalami berbagai permasalahan hidup. Permasalahan yang dihadapinya akan saling berkaitan, seperti kondisi fisik dan psikis dapat mempengaruhi keadaan sosial ekonomi. Sehingga kecendrungan lansia tergantung pada orang lain menjadi cukup besar, mereka membutuhkan bantuan atau dukungan sosial dari orang-orang di sekitarnya (Pratiwi. Y, 2018).

Dukungan sosial akan memengaruhi kualitas hidup pada lansia. Dukungan sosial didefinisikan sebagai jumlah kasih sayang, persahabatan, dan perawatan dari keluarga anggota, teman, dan individu lain (Hodge. A.M., English. D.R., Giles. G.G., Flicker. L, 2013).

Dukungan sosial biasanya didefinisikan sebagai keberadaan atau adanya seseorang yang dapat dipercaya, yang memahami, memperhatikan dan mencintai kita (Surbakti, 2013). Dukungan sosial merupakan suatu proses hubungan yang terbentuk dari individu dengan persepsi bahhwa seseorang dicintai dan dihargai, disayangi untuk memberikan bantuan kepada individu yang mengalami tekanan-tekanan dalam kehidupan (Raafiah. D, 2012).

Lansia dapat meningkatkan pemanfaatan dukungan sosial mereka jika mereka didorong untuk menghabiskan lebih banyak waktu dengan keluarga dan teman-teman, berpartisipasi aktif dalam kegiatan kolektif, dan secara aktif berbicara dengan anggota keluarga atau teman ketika menghadapi masalah atau bingung dengan sesuatu $(\mathrm{Wu} \mathrm{Z}$,
Penning MJ, Zeng W, Li S, Chappell NL, 2015).

Dukungan sosial akan mempengaruhi kualitas hidup pada lansia, dukungan sosial pada lansia dapat berupa dukungan instrumental, Dukungan instrumental adalah dukungan berupa bantuan dalam bentuk nyata atau dukungan material. Dukungan material yang diberikan oleh lansia-lansia disekitarnya adalah menyediakan dan mengambil makanan bagi lansia (Wills. L, 2010).

Dukungan sosial sebagai informasi verbal dan non-verbal berupa sarana atau nasihat, bantuan yang nyata atau tingkat laku yang diberikan oleh suatu jaringan yang akrab dengan subyek di dalam lingkungan sosialnya atau yang berupa kehadiran dan hal-hal yang dapat memberikan keuntungan emosional atau berpengaruh pada tingkat laku penerimanya (Najah. K, 2013).

Dukungan sosial lainnya adalah dukungan informasional adalah Dukungan berupa pemberian informasi yang dibutuhkan oleh individu. dukungan ini dibagi ke dalam dua bentuk. Pertama, pemberian informasi atau pengajaran suatu keahlian yang dapat memberi solusi pada suatu masalah. Kedua adalah appraisal support, yaitu pemberian informasi yang dapat membantu individu dalam mengevaluasi performance pribadinya. Dukungan ini dapat berupa pemberian informasi, nasihat, dan bimbingan (Antari. R.A., Saktika. T., Ferianto, 2016).

Dukungan sosial tersebut bertujuan untuk membantu lansia dalam memenuhi kebutuhan hidupnya. Mereka yang berusia lanjut tentunya menginginkan kehidupan yang sejahtera dimana terpetuhinya kebutuhan-kebutuhan hidupnya (Pratiwi. Y, 2018).

Dukungan sosial mempengaruhi responrespon dan perilaku lansia, sehingga ikut berdampak pada kesejahteraan atau kualitas hidup dari lansia tersebut. Lansia juga akan termotivasi oleh dukungan sosial dalam melakukan aktivitas sehari-hari serta dalam menghadap masalah dalam hidupnya (Azwan., Herlina., Karim. D, 2015).

\section{KESIMPULAN}

Lanjut usia merupakan salah satu masa perkembangan yang ditandai dengan menurunnya fungsi fisik, psikologis dan sosial. Penurunan fungsi tersebut dapat menurunkan kualitas hidup lansia. Untuk meningkatkan kualitas hidup lansia diperlukan sebuah dukungan sosial. Dukungan sosial tersebut bertujuan untuk membantu lansia dalam memenuhi kebutuhan hidupnya. 


\section{SARAN}

Untuk meningkatkan kualitas hidup Iansia dapat dilakukan dengan memberikan dukungan sosial serta kepedulian pada lansia yang diperoleh dari keluarga, kerabat dan masyarakat sangat diperlukan dan berguna bagi lansia. Dukungan yang bersumber dari

\section{DAFTAR PUSTAKA}

Antari. R.A., Saktika. T., Ferianto, 2016. Hubungan Antara Dukungan Sosial Dengan Kualitas Hidup Lansia Di Desa Cebongan Sleman Yogyakarta Tahun 2015. Media IImu Kesehatan Vol. 5, No. 1, April 2016.

Arini. D., Hamiyati., Tarma, 2016. Pengaruh Dukungan Sosial Keluarga Terhadap Kualitas Hidup Lansia Di Panti Werdha Ria Pembangunan Jakarta Timur. JKKP: Jurnal Kesejahteraan Keluarga dan

Pendidikan.

http://doi.org/10.21009/JKKP. DOI: doi.org/10.21009/JKKP.032.04.E-

ISSN: 2597-4521.

Azwan., Herlina., Karim. D, 2015. Hubungan Dukungan Sosial Teman Sebaya dengan Kualitas Hidup Lansia di Panti Sosial Tresna Werdha. JOM, 2(2). (Online)

(https://media.neliti.com/media/publica tions/183778-ID-hubungan-dukungansosial-teman-sebaya-de.pdf.

Beatrix. Y., Kodoatie., Sekplin. A.S., Sekeon., Chreisye. K.F., Mandagi, 2018. Hubungan Antara Dukungan Sosial Dan Kohesi Sosial Dengan Kualitas Hidup Pada Lansia Di Desa Tambun Kecamatan Likupang Barat Kabupaten Minahasa Utara. Jurnal KESMAS, Volume 7 Nomor 4.

Cabrera, A. J. 2015, Theoris Of Human Aging Of Molecules To Society. MOJ Immunology. 2(2). 00041.

Centers for Disease Control and Prevention (CDC). 2016. HRQOL Concepts. (Online)

(https://www.cdc.gov/hrqol/concept.ht $\mathrm{m}$.

Dewi. S.R, 2014. Buku Ajar Keperawatan Gerontik. Yogyakarta: Penerbit Deepublish.

Hodge. A.M., English. D.R., Giles. G.G., Flicker. L, $2013 . \quad$ Social Connectedness And Predictors Of Successful Ageing. Maturitas. 2013; 75;361-366. doi: orang-orang terdekat, baik dari anak, keluarga, kerabat maupun masyarakat sangat diperlukan lansia dalam menjalani sisa hidupnya karena merupakan sistem pendukung bagi lansia untuk dapat terus aktif ditengah keterbatasan yang dialaminya

10.1016/j.maturitas.2013.05.002

PMID: 23746413.

Kim. J., Song. R, Kim. K.W., Kim. J.L, 2016. Effect Of Cognitive Function, Social Activity Participation And Social Support On Quality Of Life Of Community-Dwelling Elderly. J Korean Geriatr Psychiatry. 2016 Apr;20(1):2532. Korean.

Ma. L., Li. Y., Wang. J., Zhu. H., Yang. W., Cao. R., Qian. Y., Feng. M, 2015. Research Article Quality Of Life Is Related To Social Support In Elderly Osteoporosis Patients In A Chinese Population. PLOS ONE DOI:10.1371/journal.pone.0127849 June 10, 2015.

Moher. D., Liberati. A, Tetzlaff. J., Altman. D.G, 2009. Academia And Clinic Annals Of Internal Medicine Preferred Reporting Items For Systematic Reviews And Meta-Analyses : Annals Of Internal Medicine, 151(4), 264-269. https://doi.org/10.7326/0003-4819151-4-200908180-00135.

Moser. S., Luxenberger. W., Freidl. W, 2017. The Influence Of Social Support And Coping On Quality Of Life Among Elderly With Age-Related Hearing Loss. American Journal of AudiologyResearch Article13 Jun 2017.

https://doi.org/10.1044/2017_AJA16-0083.

Najah. K, 2013. Pengaruh Dukungan Sosial dan Spiritual Terhadap Simton Depresi Pada Santri di Pesantren. Skripsi S1 Fakultas Psikologi, Universitas Islam Negeri Jakarta.

Nimas., Fitriana. A.T., Ambarani. K, 2012. Kualitas Hidup Pada Pasien Kanker Serviks yang Menjalani Pengobatan Radioterapi. Jurnal Psikologi Klinis dan Kesehatan Mental.Vol. 1. No. 02.

Nugroho, 2011. Keperawatan Gerontik dan Geriatrik. Jakarta : EGC. 
Pratiwi. Y, 2018. Pengaruh Dukungan Sosial Terhadap Kualitas Hidup Lanjut Usia Di Pusat Santunan Keluarga (Pusaka) Kecamatan Pancoran Jakarta Selatan. Program Studi Kesejahteraan Sosial Fakultas Dakwah Dan Komunikasi Universitas Islam Negeri Syarif Hidayatullah Jakarta.

Raafiah. D, 2012. Pengaruh Dukungan Sosial Terhadap Burnout Guru Sekolah Luar Biasa. Skripsi S1 Fakultas Psikologi, Universitas Islam Negeri Jakarta.

Ridho., Syuheri. S, 2016. Hubungan Dukungan Sosial Keluarga Dengan Kualitas Hidup Lansia Dengan Hipertensi Di Puskesmas Nanggalo Padang Tahun 2015. Diploma thesis, Universitas Andalas.

Rohmah. A.I.N., Purwaningsih., Bariyah. K, 2012. Kualitas Hidup Lanjut Usia. Jurnal Keperawatan. Vol.3 (2): 120132.

Sari. D.M.P., Lestari. C.Y.D., Putra. E.C.,Nashori. F, 2018. Kualitas Hidup Lansia Ditinjau Dari Sabar Dan Dukungan Sosial. JIPT. pISSN: 23018267 | elSSN: 2540-8291 Vol. 06, No.02 Agustus 2018.

Surbakti, 2013. Menata Kehidupan Pada Usia Lanjut. Jakarta: Pranita Aksara. Yusnia

Unalan. D., Gocer. S., Basturk. M., Baydur. H., Ozturk. A, 2015. Research Paper Coincidence Of Low Social Support And High Depressive Score On Quality Of Life In Elderly. European Geriatric Medicine. Volume 6, Issue 4, July 2015, Pages 319-324
Unsar. S., Dindar. I, Kurt. S, 2015. Activities Of Daily Living, Quality Of Life, Social Support And Depression Levels Of Elderly Individuals In Turkish Society. $J$ Pak Med Assoc. Vol. 65, No. 6, June 2015.

Upton. P, 2012. Psikologi Perkembangan. Jakarta: Erlangga, 2012.

Wedgeworth. M., LaRocca. M.A., Chaplin. W.F., Scogin. F, 2017. The Role Of Interpersonal Sensitivity, Social Support, And Quality Of Life In Rural Older Adults. Geriatric Nursing. Vol.38 (2017): 22-26.

WHOQOL, 1997. WHOQOL : measuring quality of life - World Health Organization.

https://apps.who.int/iris/handle/10665/ 63482.Wills. L, 2010. Functional Evaluation : The Barthelindeks. Maryland State Medical Journal 1965;14:56-61

Winahyu. K.M., Wahyuniati. S., Sekarsari. R, 2017. Hubungan Antara Persepsi Dukungan Sosial Dan Kualitas Hidup Lansia Dengan Hipertensi Di Kota Tangerang. Jurnal Ilmiah Keperawatan Indonesia.Vol 1, No 1, 2017 ISSN: 2580-3077.

Yuliati. A, 2014. Buku Ajar Keperawatan Gerontik. (T. Ari, ed). Jakarat : cv Trans Info Medika. 